\title{
Education Exploration for Blended Learning in University
}

\author{
Ling Lu ${ }^{1}$, Peng-xi Li ${ }^{1}$, Zhi-jun Liu ${ }^{1}$ and Gui-li Zhang ${ }^{2}$ \\ ${ }^{1}$ Information Center, University of Electronic Science and Technology of China, Chengdu, 610054, China \\ ${ }^{2}$ Modern Educational Technology Center, Southwest Petroleum University, Chengdu, 610500, China
}

\begin{abstract}
With the rapid development of information technology, information-based education spreads largely and deeply. The combination of on-line study and classroom-study becomes the new teaching style in blended learning, exerting the teacher's initiative and encouraging the student's passions. This article, through the education practice, discusses the influence of blended learning in University
\end{abstract} driving.

Index Terms - Blended learning, teaching platform, task-

\section{Introduction}

To train and develop 21th century needed and creative versatile talents, colleges should pay attention to both professional skills and social science and arts cultivation, those are complementary each other. The Informatization of Education Ten Year Development Plan (2011-2010) propose that further strengthening the construction of infrastructure and information resources, focusing on integration of information technology and higher education in depth, promoting modernizations and social service mode. In order to improve the quality of higher education, promote the talents cultivation level, speed up the development of network curriculum, develop the blended learning and online learning, share the teaching resources of higher quality, further promote the integration of informatization and teaching to become the research focus of university teaching reform.

At present in our country, some colleges of science and engineering pay attention to the cultivation of students professional knowledge and lack of knowledge of humanities and social science due to policy orientation, teachers and other reasons. In the liberal arts colleges, although students have a wide range of knowledge, the relative lack of scientific spirit, this also restricts the overall development. Nowadays all schools have been fully aware of the importance of penetration of science and liberal teaching in talent cultivation. At the same time, more and more applications use blended leaning mode.

Recently, with the rapid development of digital media industry, the demand of digital technical personnel increases several times over before. Our information center and education technical department, as the long-run teaching research departments, open the public optional course for the Design on Digital Video and Audio Material for science and arts. We hope students are able to learn the requirements of video-audio making course as well as arts perspective and master the normal software for dealing with video-audio material. Considering the optional course is for science and arts, the candidates will have different skills and levels and the range of knowledge will be broad, so we will take blended teaching for this course.

\section{Blended Learning}

Blended learning is derived from long distance education and enterprise training, which combines the both advantages of traditional learning and E-learning[1]. The aim is to show teacher's leading role of guiding, inspiring and supervising as well as student's initiative, activity and creative during the teaching course. The goal of blended learning is study performance. It programs the overall course framework with performance design and assessment and makes equally choices between traditional and modern media to form technical perspective of teaching or learning.

The features of blended learning principle are as follows. Firstly, the combination of teacher's leading role and student's main parts is to encourage the participation of two perspectives and change the law of waiting teaching and passive study habits. Secondly, different choice of learning information channels makes public have more information resources and channels than ever. Thirdly, rational choose of education media is to improve the study performance and decrease the learning cost effectively[2].

At the beginning of this century, western countries have studied blended learning and experienced launching, researching and promoting stages. They applied research results in problem solution and made outstanding effects in enterprise training and long distance education.

Through several years with the analysis on hundreds enterprises cases, Thomson company concluded that blended learning benefits enterprise study. IBM is benefited greatly from managerial training with blended learning and many application cases in western universities are evidence of blended learning, such as, in December 2001 the U.S.A. Florida University took blended learning to the study of supervisor administrative master course and in-service pharmaceutical course.

Our blended learning is derived from the research of Professor He Kekang, Li Kedong and Li Jiahou. They developed deep reflection according to western theory and made different definition for blended learning.

Stepped into 21th century, prevailing of internet and Elearning, people make reflection on the first generation of Elearning and web-based course study. We realize the transmission mode of solo teaching cannot provide abundant resources as well as good performance. In the following E-

This work is partially supported by teaching reform project of University of Electronic Science and Technology of China: Project No. Y02012023701153. 
learning, more and more designers try multi-channels in transmitting study resources and blended learning becomes focus within educative technology and training circles.

\section{Network Teaching Platform}

The internet is one of the greatest inventions of mankind in twenties Century, it changes the way of information transmission, people's way of thinking and living and also the world. With the development of network technology, education informatization go gradually thorough, how to give full play of teachers' leading role, how to arouse the students' learning enthusiasm and how to carry out teaching practice through the network teaching platform have become a hot topic in the reform of Higher Education Research. The construction of network teaching platform is developed from early knowledge presentation platform to discussion and exchange platform between teachers and students for the purpose of teaching and learning, so that people can exchange in the global scope, sharing the resources, cooperation in science and technology and distance learning[3]. Give full play to the network is not affected by time, space and place constrains, broaden the students receive orientation and approach of knowledge, make possibility of participatory, heuristic and hybrid teaching, the lifelong learning becomes a general trend and this is a global education continuous exploration field.

\section{Specific Practice}

A. Classroom-Teaching, Exert Teacher'S Initiative and Flexible Methods to Deepen Student's Interests.

Before the course of Design on Digital Video and Audio Material, we have elaborated the teaching target, teaching content and material, and made reasonable teaching plan. During the classroom teaching, we follow the teaching plan strictly and use heuristic education to settle the problem and show teacher's leading role. It turns out that students are interested in the new mode and have great accomplishment on learning. Before the beginning of the course, we carry out a questionnaire survey for students in the network teaching platform. The purpose is to understand the students' learning, points of interest and their existing knowledge based on audio and video, the usual hobby, experience on school organization or not. It helps us to teach more objective and make group activities more effective during the course. In network teaching platform, timely introduction of course and learning task let students follow the teaching process.

\section{B. Study after Class, Main Concern of Students and Using BB Teaching Platform as well as Abundant Digital Material, Teaching of Team Discussion to Strengthen Students' Interest}

Due to the reason of Design on Digital Video and Audio Material being an optional course of arts and hour limit, the range of knowledge is large and it is difficult to deep understanding with only classroom teaching. So we use the existing online teaching system Blackboard to enlarge the extension of digital resources and provide assistant for afterclass learning. Blackboard is the web-based teaching platform and concerned of course and towards every participant. It forms the integrated environment of word, sound and picture for teaching and learning through web and helps good communication between teacher and student. Teachers open online courses on BB and students are able to choose course and study independently.

To drive students looking over the online resources on their own initiative, we make resources richer and moderate, concise and explicit, and rational program when making them. The activities like team study, forum discussion, online Q\&A are inspiring for students. Virtual classroom and chat room help follow the assignment timely and improve the communication between teachers and students on subjects, opinions for team projects.

Such learning based on web and main concerned of students is able to push students study and research of their initiative and develop their creative thoughts. Web-based digital resource increases the student interests on course.

Digital learning resources regard teaching as same important as learning. It not only concerns teacher's teaching methods but also emphasizes on student's initiatively study and supports the blended learning greatly[5].

\section{On Teaching Practice, Case Learning and Training is to Enhance the Student'S Level of Software Operations. \\ Giving the lecture of Design on Digital Video and Audio} Material, we arrange manual practice to make digital audiovideo material. And on the key point operations, we take taskdriving method on the lecture of every case process, step by step, to let student understand why the conducts are and not only the procedures. Through the specific case, students can realize, master all kinds of audio-video software and their competence of DIY, general application is improved. After class, on the Blackboard platform of this course, our lectures are divided into three parts on website, concise and explicit to record the whole operational course and for web learning.

\section{The Analysis of Teaching Effect}

Before the beginning of the course, we carry out a questionnaire survey for students in the network teaching platform. The purpose is to understand the students' learning, points of interest and their existing knowledge based on audio and video, the usual hobby, experience on school organization or not. It helps us to teach more objective and make group activities more effective during the course. In network teaching platform, timely introduction of course and learning task let students follow the teaching process [4].

\section{Conclusion}

Applying blended learning to cultural and art optional course, combining the lectures, web-learning and practice, breaks the material or teaching resource limitations and enlarges the range of course knowledge, also encourages student's initiative, activity and creative as well as decrease the costs. How to program the study procedure and choice of material according to the demand of student are the subjects 
we keep exploring to exert teacher's leading roles on guiding, inspiring and supervising and make student accomplishment.

\section{References}

[1] K. K. He, "New Development on Teaching Theory through Blending Learning", Journal of National Academy of Education Administrational, pp. 37-48, 2005, (09).
[2] K. D. Li and J. H. Zhao, "The principle and application model of blended learning", E-education Research, pp. 1-6, 2004,(07).

[3] S. Q. Yu, Q. L. Lu and S. J. Chen, "New Teaching Mode: Blended Learning Based on Website", Chinese University Education, pp. 50-56, 2005, (10)

[4] W. T. Pan, "Blended Teaching Mode Research Based on Web Resource", Chinese Electrified Education, pp. 49-51, 2006, (08).

[5] J. J. Cen, "Blended Teaching Mode Research on Sakai", E-education Research, pp. 52-55, 2009, (09). 